\title{
Students' Perception on Online Game Mobile Legends for Vocabulary Development
}

\author{
Adil Dananjaya \& Dyah Kusumastuti \\ Universitas Muhammadiyah Purwokerto \\ (adil.dj1998@gmail.com)
}

\begin{abstract}
The purpose of this research is to discover the level of EFL students' perception of online game Mobile Legends in their vocabulary development. The researcher used questionnaire and interview as the instrument to collect the data and took 20 respondents for the questionnaire and 5 interviewees that are taken from the 8th semester students of English Education Department on 2018/2019 academic year in Universitas Muhammadiyah Purwokerto. This study got a positive result with $74 \%$, therefore can be categorized as positive perception based on Likert's scale. Moreover, it was supported by the interview result where the interviewees agreed that their vocabulary knowledge is expanding when playing Mobile Legends. Most of questionnaire and interview respondents were claiming that through playing games, Mobile Legends as one of them could increase their vocabulary knowledge, related to the spelling of new words they found from the game, the pronunciation, the use, and obviously the meaning in Indonesian. The reasons of that claiming were first from the game itself, where as an online multiplayer game it obviously makes the player, especially from Indonesia, to interact with foreign player and with it be exposed with foreign players' mother language, where it is most an English speaker, and the second reason was from their personal thought that drove them to understand English more in order to understand the game's system and to communicate well with other player from overseas to achieve victory since the game is rely on team communication.
\end{abstract}

Keywords: EFL students; game; Mobile Legends; perception; vocabulary.

Word or can be called as vocabulary is one of the important parts when it comes to learning a language, because word and language cannot be separated from each other. This notion is in line with Lin et al. (2013) who stated that "vocabulary is an integrated part of a language." While Harmon, Wood, and Keser
(2009) stated that vocabulary development is an important aspect of language learning. When someone wants to speak with other people, he or she should communicate it in a good and proper way; otherwise other people would not understand what is said. In other words, the use of correct vocabulary and proper grammar 
will ease the communication process. It is the same with Averil (2006) stated that "...the more vocabularies students know well and can use, the more meaning they can communicate in a wide variety of circumstances". In learning English, vocabulary has an important role to convey what the speaker wants to say, as stated by David Wilkins cited by Alqahtani (2015) “....while without grammar very little can be conveyed, without vocabulary nothing can be conveyed". It is why vocabulary is the most important part in a language, because it related to the four language skills, the listening, writing, speaking, and reading skill. Averil (2006) also stated that vocabulary is a central part of language.

Vocabulary learning is really needed if one wants to understand foreign language, therefore there are many ways to learn vocabulary. For example, it can be learnt from game, and it is proved by some researches that will be stated later. Game as one of the technologies that develop rapidly in this era can make it easier for students to learn. Also, it can deliver learning in an interesting way.

As we know, people like game. The report from Wijman at newzoo.com in 2018 found that there are 2.8 billion active gamers in the world, which is a fantastic amount. Nowadays, many of the games are onlinebased, where it requires Internet connection in order to operate, including Mobile Legends. The main purpose of game, both online and offline, is only for entertainment, or at least that is how most people perceive. It is the same as Ahmadi \& Munawar (2005) who stated that the purposes of playing game are to get fun and entertainment.

Human perception according to Walgito (2010) said that perception begins from our five senses, the hearing, smelling, tasting, touching, and seeing or vision. While Slameto (2010) explains that "Perception is a process related to the move of message or information into human's brain". Perception can be in form of information, sign or cues, object, condition, and situation. Perception is related with people's opinion towards stimulus, causing the individual to make a conclusion about what they experienced. Perception can be described as how we see the world around us.

Through game, EFL learners can possibly feel interested, fun, meet new words that they never knew before, and reduce their anxiety level. It is the same as Young \& Wang's (2013) research result in which game can reduce students' anxiety in learning English. Therefore, vocabulary learning will become easier and the EFL learners will be motivated. While Reinders and Wattana (2011) explained that the effects of online game on outclass language acquisition are negative and positive. It is positive as the game provides access to interactions with foreign players, in which they have to use English to communicate. It opens chances for the increase of vocabulary and grammar use as the impact of the interaction.

The previous studies in this theme are few, and the researcher took 4 of them, the result of those studies indicated "positive" impact, Sudharto (2018) in his research entitled Phenomenon of Online Game Mobile Legends on North Sumatera's College Students concluded that the respondents gained ability to use foreign language (English). While Ismail (2016) with the research title Phenomenon of Online Game Defense of The Ancients (DoTA 2) on Malang College Students' Academic Achievements stated that the respondents of his research were experiencing the development in their English proficiency. Then Nurafidha (2018) in her research title The Acquisition of English through Playing DoTA also claimed that the respondents' vocabulary is growing. Wijiarti (2016) in her research entitled Impact of Online Game towards English Learning concluded that the respondents is claiming that they are experiencing their ability to use English in both written and spoken is increasing.

Based on the previous studies about how games can affect students' English acquisition and had a positive result, the 
researcher were curious and wants to examine about UMP English Education Department students' perception on Mobile Legends for vocabulary learning.

\section{Method}

This research used survey as the method of the research where the instruments to collect the data were closed-questionnaire and structured-interview. These instruments were used considering that closed-questionnaire is the most suitable instrument in this research, while the structured interview can aid the researcher in asking the questions. This research's data collection was conducted on July 2019 in Universitas Muhammadiyah Purwokerto.

The subject of the research was students of English Education Department. There were 20 respondents for the questionnaire, and 5 interviewees for the interview. The samples were taken by using purposive sampling technique where the samples only they who have been playing Mobile Legends for at least 4 months to avoid bias of the data. The questionnaire has 5 indicators, namely new words, spelling, pronunciation, word
Table 2. Interview's Indicators

\begin{tabular}{|l|l|l|}
\hline No. & Aspect & $\begin{array}{l}\text { Number } \\
\text { of Items }\end{array}$ \\
\hline 1. & New words & 1 \\
\cline { 3 - 3 } & & 2 \\
\hline 2. & Word classes & 3 \\
\hline 3. & Pronunciation & 4 \\
\hline 4. & General question & 5 \\
\hline
\end{tabular}

classes, and word use. Each of them contains up to 5 statements, forming 20 -statementsquestionnaire. The interview has 4 indicators with 1 until 2 questions for each indicator.

The questionnaires were distributed through Google Form link to the respondents and the results play the role as the main data source, while the interview results as the assisting data to support and strengthen the main data source by using three steps, there are data reduction, data display, and the last is conclusions. To avoid confusion, the indicators for both questionnaire and interview were used, as shown in Table 1 and Table 2.

\section{Results and Discussion}

The percentage of perception of

Table 1. Questionnaire's Indicators

\begin{tabular}{|c|c|c|c|}
\hline No. & Aspects & Indicators & $\begin{array}{c}\text { Item } \\
\text { Number }\end{array}$ \\
\hline \multirow{5}{*}{1.} & \multirow{5}{*}{ New Words } & \multirow{5}{*}{$\begin{array}{l}\text { Students meet and are able to discover the meaning, syn- } \\
\text { onym, and antonym of new vocabularies. }\end{array}$} & 1 \\
\hline & & & 2 \\
\hline & & & 3 \\
\hline & & & 4 \\
\hline & & & 5 \\
\hline \multirow{2}{*}{2} & \multirow{2}{*}{ Spelling } & \multirow{2}{*}{ Students are able to discover the spelling of certain words. } & 6 \\
\hline & & & 7 \\
\hline \multirow{2}{*}{3} & \multirow{2}{*}{ Pronunciation } & \multirow{2}{*}{$\begin{array}{l}\text { Students are able pronounce the new vocabularies cor- } \\
\text { rectly. }\end{array}$} & 8 \\
\hline & & & 9 \\
\hline 4 & Word Classes & $\begin{array}{l}\text { Students are able to identify new vocabularies' part of } \\
\text { speech. }\end{array}$ & 10 \\
\hline \multirow{3}{*}{5.} & \multirow{3}{*}{$\begin{array}{l}\text { Word Use (grammatical pat- } \\
\text { tern and the impolite words) }\end{array}$} & \multirow{3}{*}{ Students are able to know the use of new vocabularies. } & 11 \\
\hline & & & 12 \\
\hline & & & 13 \\
\hline
\end{tabular}


online game Mobile Legends in vocabulary development below has been calculated and the results drawn by using the following formula:

$$
P=\frac{n}{N} \times 100 \%
$$

$\mathrm{P}=$ Perception's percentage

$\mathrm{n}=$ Total percentage of indicators

$\mathrm{N}=$ Total number of indicators

The following calculation based on the formula above shows the final result:

$$
\begin{aligned}
P & =\frac{(81+72+71+72+77)}{5} \times 100 \% \\
& =\frac{372}{5} \times 100 \% \\
& =74 \%
\end{aligned}
$$

From the end result above, the perception's percentage of online game Mobile Legends in vocabulary development can be concluded as "positive" because the results is above $60 \%$. It is based on the Likert's scale that can be seen Table 3 .

The researcher used 2 kinds of instruments; the main instrument is questionnaire which resulted on "positive perception" with the result of $74 \%$, exceeding the minimum threshold of positive category in the Likert's scale table, the interview as a supportive instrument to strengthen the gained data from the questionnaire. In this section, the researcher will discuss the result.

The final result of the questionnaire was drawn by using the formula above, where the total percentage of indicators is divided by total number of indicators. The 'score' column is obtained by summarizing the calculation of the total respondents' score who chose the options: strongly disagree, disagree, neutral, agree and strongly agree, the score is 1, 2, 3, 4 , and 5 respectively. The description can be seen in Table 4.

\section{New Vocabularies}

From the result of the questionnaire, the researcher drew a conclusion that all of the respondents have a very high percentage category on discovering new vocabularies when playing Mobile Legends, reaching 81\% points, which means that they have a positive perception on it. This is supported by the interview data that they found new vocabularies from the items' name, items' description, heroes' background story, and heroes' skills. Assisted by dictionary or experience to relate the new vocabularies with the vocab they have already known are also stated in the interview to support the questionnaire result.

\section{Spelling}

The result of the questionnaire about this aspect indicted that the respondents had a positive perception about discovering a different spelling type of the same word between in Mobile Legends and daily lives' texts. The result was $72 \%$ therefore it belongs to high level percentage.

\section{Pronunciation}

The questionnaire items resulted was reached $71 \%$ from this aspects, which belongs to high level percentage and the respondents also has positive perception about Mobile Legends related to this aspect. It is also supported by the interview result, where the interviewee claimed that Mobile Legends' system announcer and Mobile Legends' MOBA-system allow them to play with their friends and even with foreigner helped them to learn some pronunciation.

\section{Word Classes}

This aspect's questionnaire result indicated $72 \%$ therefore it is a high level percentage means that the respondents had positive perception on this aspect. The interview data supported this result as the interviewee said that they could identify the new words' class by using contextual meaning, and simply looking at the category of the menu inside Mobile Legends, example the heroes' skills contains many verb, 
or heroes' story contains many adverb.

Word Use

There are three items from this aspect that the total result reached $77 \%$ point, thus belongs to high level percentage. The respondents also having positive perception on Mobile Legends' vocabulary, they said in the interview that it could be used in daily lives, by that is on social media updates for the example of use. It is also supported by some point in the interview section where the interviewee stated that the Mobile Legends' heroes' quote could be a motivation in daily lives.

That is the end of the discussion, playing game is fun, even though spending a lot of time in games could probably decrease learning achievement but, through game it is proven that people can also learn something in it, in this case is the increasing vocabulary knowledge as stated by Reinders and Wattana (2011) that playing game has an impact on English acquisition, emphasized on the increase of vocabulary and grammar use.

\section{Conclusion}

After doing the research by using questionnaire and interview, the result of the research could be concluded that the students' perception towards online game Mobile Legends in their vocabulary development is positive.

The result is positive, reaching a $74 \%$ in the final result, therefore it is belongs to positive perception, the data shown that the respondents agreed that they met many new vocabularies, discovered how to spell and pronounce the words by the game's system and others that assisted them, even ever used the new vocabularies in their daily lives, and they claimed that their vocabulary knowledge is expanding when playing Mobile Legends. Besides playing for fun, the students can also learn about English from this game.

\section{References}

Ahmadi, \& Munawar. (2005). Psikologi Perkembangan. Jakarta: Rineka Cipta.

Averil, C. (2006). Essentials of Teaching Academic Vocabulary. USA: Houghton Mifflin Company.

Harmon, J. M., Wood, K. D., \& Keser, K. (2009). Promoting Vocabulary Learning with Interactive Word Wall. Middle School Journal.

Ismail, K. A. (2016). Fenomena Permainan Game Online Defense of The Ancients 2 (DOTA 2) pada Prestasi Akademik Mahasiswa Perguruan Tinggi di Kota Malang. Malang: Universitas Islam Negeri Maulana Malik Ibrahim Malang. Retreved from http://etheses.uinmalang.ac.id/3814/1/09130036.pdf. Accessed on May 17, 2019.

Lin, J., Wang, A., \& Du, W. (2013). Learning English Vocabulary in the Chinese Context.

Nurafidha, R. (2018). The Acquisition of English Through Playing DOTA (Defence of The Ancients) 2: A Lived-Experience Study. Yogyakarta: Universitas Sanatha Dharma Yogyakarta. Retrieved from http://repositori.usu.ac.id/bitstream/ handle/123456789/7057/140904065. pdf? sequence $=1$ \&isAllowed $=y$. Accessed on May 16, 2019.

Reinders, \& Wattana. (2011). Learn English or Die: The Effects of Digital Games on Interaction a Willingness to Communicate in a Foreign Language. Article. Available at: http://www. digitalcultureaneducation.com/cms/ wpcontent/uploads/2011/04/dce1094_ reinders_2011.pdf

Slameto. (2010). Belajar dan Faktor-Faktor yang Mempengaruhinya. Jakarta: Rineka Cipta.

Sudharto, A. R. (2018). Fenomena Game 
Online Mobile Legends di Kalangan Mahasiswa (Studi Kasus pada Mahasiswa Universitas Sumatera Utara). Medan: Universitas Sumatera Utara. Retrieved from http://repositori.usu.ac.id/ handle/123456789/7057. Accessed on May 23, 2019.

Walgito, B. (2010). Pengantar Psikologi Umum. Yogyakarta: Andi Offset.

Wijiarti, D. N. (2016). Dampak Penggunaan Game Online Terhadap Pembelajaran Bahasa Inggris (Ditinjau dari Persepsi Mahasiswa). Manado: Universitas Sam Ratulangi. Retrieved from https://media. neliti.com/media/publications/80571ID-dampak-penggunaan-game-onlineterhadap-p.pdf. Accessed on May 23, 2019.

Wijman, T. (2018, June 20). Newzoo. Dipetik May 02, 2019, dari newzoo.com: https:// newzoo.com/insights/articles/newzoos2018-report-insights-into-the-137-9billion-global-games-market/

Young, S. S., \& Wang, Y. H. (2014). The Game Embedded CALL System to Faciliate English Vocabulary Acquisition and Pronounciation. Journals of Educational Technology and Society, 14. 